\title{
Setting up the financing institution of the European Economic Community: the creation of the European Investment Bank (1955-1957)
}

\author{
Lucia COPPOLARO
}

Since its creation in 1958, the European Investment Bank (EIB) has served as the financial institution of the European Economic Community (EEC) and of the EEC's successor, the European Union (EU). ${ }^{1}$ By borrowing substantial funds on the international capital markets and then lending those funds to finance investments, the activity of the EIB is intended to channel capital in such a way that improves the abilities of the EU's member states and their firms to adapt to the increased competition created by the common market, while also reducing inequalities among the regions and between economic sectors.

This article analyses the origin of the EIB by tracing the discussions between 1955 and 1957 which led to its creation. At the same time, it seeks to shed further light on how the EEC's founding treaty - the Treaty of Rome - was negotiated, the different aims the founding members pursued during these negotiations, and how these differences were ultimately accommodated.

First the article tries to show that the establishment of the EIB was prompted by the understanding that a financial institution would be required to ensure that the transition to a common market was smooth and balanced - despite the marked differences between the economies of the member states - by directing capital towards under-developed regions and struggling industries. The idea of using an autonomous lending institution to improve the process of economic integration was consistent with the general attitude of the governments to the creation of the EEC, namely that specific institutional measures would be required to minimise and offset the difficulties and negative effects which would predictably arise after the introduction of a common market.

Second, the article illustrates that, despite this common ground, no agreement existed on the exact function and structure of the EIB and this was due to the particular aims which each government pursued in the Treaty of Rome negotiations and to differences in their varied economic structures. There was considerable diversity

1. The author acknowledges her gratitude to the European Investment Bank for financing this research, to the Institute of Social Sciences of the University of Lisbon for financing the completion of this article, and the JEIH anonymous reviewers for the many useful comments they provided. The following archival sources have been used: Historical archives of the European Union (HAEU), Florence (Italy), Banque Européenne d'Investissement (BEI): Rapports Annuels 1958, 1959, 1960; the Procès-verbaux du Conseil d'administration 1958, 1959, 1960; Création de la BEI - G. Sertoli: Propositions préliminaires sur le Fonds d'investissement; Travaux du Groupe ad hoc pour le Fonds d'investissement BEI 1007 - 1022; CM3/NEGO Négociations du traité instituant le CEE et la CEEA: Files used: $1-10 ; 36-43 ; 83-93 ; 104-155 ; 248-251$. Ministère des Affaires Etrangères Français (MAEF), Documents diplomatiques français (DDF) 1955, 1956, 1957. 
among the member states' positions: at one end of the spectrum, Germany supported the creation of a bank that would borrow on the international capital market to finance projects of a viable nature, whilst at the other end, Italy wanted the establishment of a fund that would lend to projects with social aims, financed directly by the member states. The negotiations which ultimately led to the creation of the EIB oscillated between these two poles.

The final choice to set up the EIB not as a fund but as a bank that could participate in international capital markets required the EEC members not only to provide the EIB with its own financial resources but also its own legal personality - unlike the EEC - so that it could, by its autonomy of action, earn credibility within the capital markets. By this decision, the EIB became the most supranational of the institutions created within the EEC.

\section{Linking the common market to an investment institution}

The idea of establishing a financial institution that could promote investments at the European level had been raised prior to the Treaty of Rome negotiations. Already in late 1949 the French ministry of Finance suggested it to the Organisation for European Economic Cooperation (OEEC), premised on the notion that that the liberalization of trade promoted by such an institution would have to be accompanied by measures to harmonize the economies of the participating countries. In order to balance the effects of trade liberalization, the French ministry of Finance proposed a schedule of investments to be carried out by a European investment fund with a view to increase the competitiveness of the European industries in general, to promote a balanced development of the regions of the member states, and to improve their economic and social cohesion. This plan did not receive the support of the entire French government, nor did it receive the support of the liberal politicians outside France, who were opposed to the idea of harmonization and planning. ${ }^{2}$

In 1953 the Dutch Foreign minister Johan Willem Beyen presented to the Council of ministers of the European Coal and Steel Community (ECSC) a memorandum containing a plan for wider economic integration through the establishment of a common market, envisaging also a European fund tasked with the modernization and reconversion of the economies of the member states. The Dutch proposed a reconversion fund rather than an investment fund, but like the French proposal, it was

2. On the early attempts to create a European Investments Bank, see M. Kipping, La Banque Européenne d'Investissement, de l'idée à la réalité (1949-1968), in: Ministère de l'Economie, des Finances et de l'Industrie, Le rôle des ministères des Finances et de l'Economie dans la construction européenne (1957-1978), Comité pour l'Histoire Economique et Financière de la France, actes du colloque de mai 1999, pp.526-542. See also the recently published volume by E. BUSSIËRE, M. DUMOULIN, E. WILLAERT (eds.), La Banque de l'Union européenne. La BEI, 1958-2008, Imp. Centrale, Luxembourg, 2008, pp.23-35, which represents the most complete work on the history of the EIB. 
founded on the belief that the conditions of increased competition which would be engendered by the introduction of a common market ought to be tempered by specific instruments to enable member states to adapt to the new environment. In reaction to the Dutch plan for a reconversion fund, the French government again suggested that the ECSC members should coordinate their investments so as to increase the productivity of their industries. The Dutch memorandum was not accepted by the Council of ministers of the ECSC, and so both the Dutch plan and the French proposal came to nothing. ${ }^{3}$ While neither the Dutch nor the French initiatives were specific on the methods by which their proposed funds would raise the required financial resources, both initiatives appeared to understand the necessity of coupling the establishment of a common market with measures to mitigate its impact by creating a finance institution to channel investments.

In May 1955 the Benelux countries presented to the ECSC a memorandum based upon Beyen's plan of 1953, which supported the creation of a common market, called for sectoral integration for the electricity, transport and nuclear energy sectors, and proposed also the creation of a reconversion fund. Following this Benelux initiative, the idea of creating a common market was added to the agenda of the six members of the ECSC (the Six) at the Messina conference in June 1955. ${ }^{4}$ Within this framework, the plan for an investment fund was again raised. The Italian delegation tabled a memorandum which, while agreeing to the plan for establishing a common market, at the same time proposed that the countries forming a common market should not only facilitate the necessary adjustment of their economies through a reconversion fund, but should also pursue a policy of economic growth and of investment in areas that lacked capital. Italy therefore called for the creation of an investment fund so that capital could be channelled to regions - like the South of Italy - which traditionally lacked them. ${ }^{5}$ The German government also called for the creation of an investment fund that would encourage productive investments and help to iron out the wide and socially dangerous disparities in living standards between the regions of the future

3. On the Dutch initiative, see HAEU CM3 - NEGO 3, Mémorandum du Gouvernement des Pays-Bas concernant la Communauté européenne, 05.03.1953. On the Dutch plan, see R.T. Griffith, The Beyen Plan, in: R.T. GriffithS (ed.), The Netherlands and the Integration of Europe, 1947-1957, NEHA, Amsterdam, 1990, pp.165-182. On the French initiative, see MAEF - DDF 1955 (I) - Document 301, Note du Département «Plan Beyen», 26.05.1955. Though dated 1955 this document describes the position of the French government in 1953.

4. HAEU CM3 - NEGO 3, Mémorandum des pays Benelux aux six pays de la CECA, 21.04.1955. On the Dutch initiative and how this led to the creation of the EEC see A.S. MILWARD, The European Rescue of the Nation-State, Routledge, London, $2^{\text {nd }}$ ed., 2000, chapter 4, pp.119-223.

5. HAEU CM3 - NEGO 3, Mémorandum du Gouvernement italien sur la poursuite de l'intégration, 01.06.1955. On the Italian attitude in Messina see, E. SERRA, L'Italia e la conferenza di Messina, in: E. SERRA (ed.), Il Rilancio dell' Europa e i Trattati di Roma, Nomos, Baden-Baden, 1989, pp. 93-124. 
member states. France too supported the creation of an investment fund, having already suggested a coordination of investments in 1949 and again in $1953 .{ }^{6}$

The Messina conference ended with a resolution calling for a study on integration in the transport and energy fields and the establishment of a common market. ${ }^{7}$ Taking up the Benelux memorandum and the memoranda tabled by Germany and Italy, the Foreign ministers agreed that further economic integration could be based on common institutions, a common market, coordinated social policies, a gradual fusion of national economies, and sectoral integration in the field of energy and transportation. The resolution stated that:

"The creation of a European Investment Fund will be studied. The objective of this fund would be the joint development of European economic potentialities and in particular the development of the less developed regions of the participant states".

It therefore highlighted the fact that the fund would be needed to contribute to fostering economic development, in particular in regions that were lagging behind, as had been demanded above all by Italy. ${ }^{8}$

The Messina conference showed that the aim of setting up an investment institution was shared among the Six, who linked it to the establishment of the common market. The six governments were clearly aware that the differences in their respective national economic structures would present obstacles to any integration. Certain regions were more developed than others; productivity varied among regions, member states and sectors; and there were vast disparities in the availability of infrastructure in different parts of the member states, with some regions characterised by a lack of communications or even access to electricity. To overcome these obstacles and to promote the smooth implementation of a balanced common market, large-scale investments were necessary, otherwise it remained possible that the intensification of competition would exacerbate the existing inequalities across regions, states and sectors. Thus, the establishment of an investment institution was widely considered to be a necessary corollary of the creation of a common market. ${ }^{9}$

6. For the German memorandum see HAEU CM3 - NEGO 3, Mémorandum du Gouvernement fédéral sur la poursuite de l'intégration, 01.06.1955. On the French position see MAEF DDF 1955 (I) Document 301, Note du Département «Plan Beyen», 26.05.1955, and Document 332, Circulaire 49, Pinay, ministre des Affaires étrangères aux représentants diplomatiques de France à l'étranger, 10.05.1955.

7. The literature on the Messina conference is very extensive. See among the others, E. SERRA (ed.), op.cit.

8. For the Messina resolution see HAEU - CM3 NEGO 3 - Réunion des ministres des Affaires étrangères, Messine, 01-03.06.1955.

9. HAEU - CM3 NEGO 2 - PV de la réunion des ministres des Affaires étrangères des Etats membres de la CECA, Messina 01.06.1955, and EIB Annual Report 1958. The first annual report of the EIB illustrates, in addition to the first year of activities, the origins of the EIB since the Messina conference. 


\section{The Spaak Report and the creation of an investment institution}

In order to build upon the Messina resolution, the six Foreign ministers agreed to set up an intergovernmental committee, headed by Paul-Henri Spaak. The intergovernmental committee met for the first time on 9 July 1955 in Brussels and set up four committees to deal with conventional energy, nuclear energy, transport and public work, and the common market, investments and social issues. This last committee had the task of studying the optimal methods and timetable for a number of objectives: dismantling restrictions on the free circulation of goods, people, services and capital; setting up a common external tariff; achieving harmonization in the economic, financial and social fields; creating the institutions of the new community, including, possibly, a fund of investment and reconversion.

Given the technicalities involved in creating a new investment fund, the task of examining the issue was assigned to a sub-group of experts chaired by the Italian Giuseppe Di Nardi. ${ }^{10}$ To guide its drafting on the fund, the sub-group considered the statute of the International Bank for Reconstruction and Development, the first of the institutions which today constitute the World Bank group, and the only international organisation dealing with investments at that time. In October 1955 the sub-group issued the Di Nardi report which revealed that, while the Six all agreed on the need to create an investment fund, they did not agree on its exact function or nature. ${ }^{11} \mathrm{In}$ fact, the apparent divergence in their attitudes was attributable to the different economic approaches which each state had adopted in the negotiations, which in turn were attributable to their different levels of economic development.

When the plans to achieve comprehensive economic integration were debated in Messina, discussions took place on the instruments and approaches to be used to make the common market work. The debate concentrated, in particular, on the economic framework to be used. The Federal Republic of Germany - and in particular the ministry of Economics - and the Benelux countries supported a liberal economic policy, whereas Italy and France advocated a more dirigiste approach. This debate touched also upon the creation of an investment institution, and dictated the entire course of negotiations leading to the creation of the EIB. ${ }^{12}$ Germany and the Benelux countries supported the creation of a fund that borrowed on the international capital market in order to finance its lending, which would be based purely on economic needs and limited to productive investments. Following this approach, the fund had to be a bank that would provide loans - and not grants - run with business principles and independent from the political control of the member states. ${ }^{13}$

10. MAEF DDF 1955 (II) - Document 22, Télégramme n.452 à 458, M. Rivière, Ambassadeur de France a Bruxelles à M.Pinay, ministre des Affaires étrangères, 09.07.1955; Document 48, M. Rivière, ambassadeur de France à Bruxelles, à M.Pinay, ministre des Affaires étrangères, 20.07.1955.

11. HAEU - CM3 NEGO 43 Conférence intergouvernementale créée par la conférence de Messine, Rapport présenté par M. le professeur G. Di Nardi au nom de la sous-commission des investissements [...], 29.10.1955.

12. On this aspect, see H.J. Kursters, The Origins of the EEC Treaty, in: E. SERRA, op.cit., pp.211-238.

13. HAEU - BEI Création de la BEI - G. Sertoli 1000, Témoignage Sertoli, 28.10.1994. 
The positions of France and Italy differed in important respects. In the French view, the fund had to be established with a fairly broad function so that it would have the opportunity to conduct operations in various fields, most notably the rationalisation of the productivity structure, the development of less-advanced regions, and the reconversion of enterprises. In principle, the fund would finance economically viable projects. This financing would take a wide range of forms: from loans and guarantees to straight subsidies, as well as allowances to workers to help them find new employment. Thus, the French considered that the fund ought to play a significant role in the private sector - as evidenced by the need for reconversion - and so should provide not only loans and guarantees but also redeployment allowances and grants. In this sense, France wanted the fund to play a social role in curtailing the negative effects that would likely arise from the implementation of the common market. As for the financial resources, in the French view, the fund would operate as a real 'banque d'investissement européenne', with capital provided by the budget contributions of member states, to which would then be added resources obtained by borrowing on the international capital market. France therefore wanted an institution which was essentially a bank, but one which could also, in some situations, act as a fund. 14

During the negotiations leading to the establishment of the EEC, the Italian government adopted a policy of broadening the scope of the prospective Community by including support for those regions which were lagging behind their neighbours in terms of economic and social development. This policy was reflected in the Italian position with respect to the creation of the fund and the use of its resources. According to Italy, the Community was obliged to reduce regional imbalances by boosting the development of the less-advanced areas and, in this context, the fund should serve as a source for investments in Southern Italy. ${ }^{15}$ Moreover, as the implementation of the common market could be expected to produce both economic and social consequences - for workers generally, but especially those in under-developed areas - Italy, the least developed country of the Six, argued that the investment fund should act in accordance also with social principles. Therefore, Italy urged to insert some social dimension in the fund's guiding principles in order to mitigate the negative impact anticipated with the advent of increased competition. In short, as the Italians asserted, the fund should channel capital to the South of Italy and to consider social objectives

14. The French position is described in HAEU - CM3 NEGO 39 - mémorandum de la délégation française sur l'établissement d'un marché commun, 14.09.1955; MAEF DDF 1955 (II) - Document 207, Note de la direction des Affaires économiques et financières (service de coopération économique «Etablissement d’un marché commun général», 13.10.1955.

15. $\mathrm{HAEU}-\mathrm{CM} 3 \mathrm{NEGO} 2-\mathrm{PV}$ de la réunion des ministres des Affaires étrangères des Etats membres de la CECA, Messina, 01.06.1955; NEGO 43 - Note de la délégation italienne «Fonds européen d'investissements», 19.07.1955. 
and impacts when making any lending decisions. ${ }^{16}$ The distance between the German and the Italian position was well summarised by an official of the Italian Treasury, who suggested that while Italy longed for a kind of 'Cassa per il Mezzogiorno', Germany wanted a bank. ${ }^{17}$

It was against this set of positions that the sub-group on investments produced a report on the investment fund that was then incorporated in the Spaak Report presented to the ministers of Foreign affairs of the ECSC in April 1956. ${ }^{18}$ The plan for an investment fund was contained in the section of the report entitled 'The development and full utilization of European resources'. The report emphasised that the common duty and interest of all member states in developing disadvantaged areas was justified on the basis of past experience. The cases of Italian unification after 1860 and of the United States after the Civil War showed that disparities between regions could grow if public bodies did not intervene immediately to promote the conditions necessary to develop the means of production. Thus the Report presented the view that an investment fund was required to pump investment into the lessdeveloped areas in order to provide a steady form of economic development which would minimise the regional and social imbalances caused by increasing competition. It was necessary to combine a liberal objective - the implementation of the common market - with a public institution licensed to mitigate the consequences of such implementation.

The Spaak Report set out precise recommendations on the nature and the structure of the proposed institution, which it envisaged as more of a bank than a fund, thereby accepting the German position over the Italian one. The institution would only finance investment projects that were productive in nature and which might generate profits or other income. The sources of the fund would be raised on the international capital market and not through contributions from the budgets of the member states. This meant that the fund would be required to conduct itself as a credible borrower: its creditworthiness would depend not only on the way in which it was organised and governed, but also upon its ability to ensure that it had access to available capital and resources with which it could fulfil its various tasks and obligations. The Spaak Report suggested that the initial capital of the investment fund, on which the fund's credit standing would be based at first, would have to be subscribed by the member states and, by comparison with the World Bank's basic capital of USD 10,000 million, the Spaak Report nominated a figure of USD 1,000 million for the new fund's initial capital. This initial capital need not be fully paid up, but could be made available to

16. HAEU - BEI - 1021 Conférence intergouvernementale pour le Marché commun et l'Euratom Groupe du Marché commun, Rapport sur les travaux du Groupe ad hoc chargé d'élaborer le statut du Fonds d'Investissement, 27.11.1956. This document summarises the attitudes of the ECSC Six since the beginning of the negotiations. For an account of Italy's attempt to insert a social provision in the Treaty of Rome, see A. VARSORI (ed), Il Comitato Economico e Sociale nella costruzione europea, Marsilio, Venezia, 2000.

17. E. BUSSIÈRE, M. DUMOULIN, E. WILLAERT (eds.), op.cit., p.38.

18. For the Spaak Report see HAEU - CM3 NEGO 89 Intergouvernamental Committee of the Messina Conference - Report by the Heads of Delegations to the Foreign Ministers, 21.04.1956. 
the extent of only $25 \%$. The authorities administering the capital resources of the fund would be prevented from calling upon the member states to make additional contributions, in order to encourage them to adopt a sensible and sustainable approach to borrowing on the international capital markets. However, the Spaak Report preserved the possibility of member states making additional contributions, but only for the specific purpose of raising the credit standing of the institution and only under certain conditions. Should the member states decide to make such an additional contribution during the first five years of the EEC's existence, this would be regarded as an increase in the original capital. Ultimately, the Report's model was designed with the intention of reducing as far as possible the need for such additional contributions, and so required the fund to make every effort to raise the resources it required on the capital markets.

As for the structure of the fund, the most senior body would be the Board of governors, which would be composed of representatives of the member states and of the European Commission. The Board of governors would give directives to a managing board that would work according to accepted banking principles. In view of the fund's dual role of participating in international capital markets while also implementing the creation of the European common market, its formal status was, necessarily, two-fold: it was to be both an institution of the EEC and an independent entity with legal personality.

Concerning the functions of the fund, the Spaak Report, apparently accepting the French and Italian requests, pinpointed three major fields of activities. First, the fund would contribute to the financing of projects of European character and interest though no definition was given of this notion - which, on the account of their size or their nature, could not easily be financed by the individual states themselves. The second task would be to promote the development of lagging-behind areas through investments in the public sector, and especially infrastructure such as roads, ports and communication facilities. These investments were considered essential for a balanced and smooth implementation of the common market, and were deemed likely to generate greater opportunities for employment. The third field of action comprised investments in the private sector and the reconversion and creation of new enterprises. This action was thought to be vital to help maintain employment in conditions of increasing productivity while enabling the best use of available resources in accordance with the ultimate aim of adapting gradually to the common market. This policy was intended to minimise the closure of enterprises, worker dismissals and work stoppages while also increasing the prospects for re-employing those workers who did lose their jobs. Efforts to guarantee productive employment by reconverting enterprises or creating new ones were endorsed as priorities in view of their great social importance. It should be noted that this third field of action had not been mentioned by the final statement of the Messina declaration and was inserted as a consequence of French pressure. ${ }^{19}$

19. On the French effort to include this aspect among the tasks of the EIB, see HAEU, EIB Annual Report 1958. 
As these details indicate, the thrust of the Spaak Report's analysis was that the creation of an investment fund with an assured capital of its own and capable of operating on the international markets as a borrower of the highest standing appeared to be indispensable for the balanced and smooth development of the common market. However, the Six disagreed on the functioning, financing and structure of the fund. ${ }^{20}$ Germany wanted to restrict the fund's field of activity, in opposition to the French position, and to confine the fund to financing only those projects capable of generating rental income. Italy in turn wanted the fund to concentrate on the development of under-developed regions and wanted social aspects also to be considered when financing decisions were to be made. Intending to apply pressure to the other governments, the Italian minister of Foreign affairs, Gaetano Martino, underlined the effort the Italian government was making to enhance the development of the laggingbehind areas of the country and warned that these efforts should not be undermined by the integration of the economies of the Six. In this context, concluded the Italian minister, the immediate creation a European fund for investments and reconversion was indispensable. ${ }^{21}$

The Venice conference of the Foreign ministers of the ECSC in May 1956 approved the Spaak Report - including the section dealing with the investment fund and upheld it as the basis for the intergovernmental negotiations on the creation of the EEC. As a result, discussions among the ECSC Six proceeded with the Spaak Report serving as something of a blueprint. ${ }^{22}$

\section{Finding a compromise between two stances}

The negotiations to establish what would become the EEC and Euratom (the European Atomic Energy Agency) commenced in Brussels at the end of June 1956 and ended in February 1957. The heads of the national delegations formed an organizing committee, chaired by Spaak, and set up two groups, one dealing with the creation of the common market and the second with the energy agency. Concerning the fund, the job of the Common market Group (CMG) was to draft two articles defining the fund and its functions for insertion into the Treaty of the EEC. A Statute, to be annexed to the Treaty, specifying all the characteristics and the structure of the fund was to be drafted by a sub-group.

20. For the position of the six governments during the discussions over the Spaak Report, see HAEU CM3 NEGO 42 PV de la conférence des ministres des Affaires étrangères des Etats membres de la CECA, Bruxelles, 11-12.02.1956.

21. On the French position, see MAEF DDF 1956 (II) - Document 265, Note de la Direction Générale des Affaires économiques et financières «Marché commun», 21.04.1956; on the Italian position, see MAEF DDF 1956 (II) - Document 377, Project de procès-verbal de la conférence des ministres des Affaires étrangères des Etats membres de la CECA, Venise, 29-30.05.1956.

22. For the text of the declaration of Venice of the ministers of Foreign affairs, see MAEF DDF 1956 (II) - Document 377, Project de procès-verbal [...], 29-30.05.1956. 
Negotiations continued to address the functions of the fund, its institutional organisation, voting procedure, financial resources and credit policy. With respect to the functions of the fund, Germany and the Benelux countries were in favour of limiting the operational scope of the institution, while France and Italy preferred to enlarge it. The CMG essentially accepted the proposal of the Spaak Report, and agreed to entrust the fund with several tasks: to favour the development of lagging-behind regions; to support reconversion operations; to sponsor the creation of new enterprises; and to fund projects that, by their nature, could not be financed by any one member state on its own. Germany and the Netherlands wanted a general preamble in the Treaty to specify that projects had to be of European character and interest if they were to qualify for financing. Italy and France, on the other hand, wanted to follow the approach of the Spaak Report which had mentioned the 'European character and interest' clause only with reference to works that by their nature could not be financed by one member state. ${ }^{23}$ On top of this, France wanted to provide the fund with a broader role than that assigned by the Spaak Report, giving it also the authority to finance projects aimed at modernising enterprises. Therefore the Paris government wanted the fund to play a key role in helping industry to adjust to the increased competition expected with the commencement of the common market. ${ }^{24}$ Italy supported the French position, but at the same time wanted the fund to treat the development of the less-advanced areas as a priority and to have this priority clearly stipulated in the articles of the Treaty of Rome implementing the fund. Having the least developed economy and many of the poorest regions in Western Europe, Italy was determined to enshrine regional development as one of the fundamental imperatives of the common market. According to the Italian government, those areas might only benefit from wage cost differentials or increased productivity if they were provided with suitable infrastructure. For this reason Italy stressed the importance of measures targeting disadvantaged areas for job creation and regional development projects. ${ }^{25}$ Luxembourg, France and Germany opposed the inclusion of a clause which would give so much relevance to a common regional policy, preferring instead to leave the fund a greater degree of freedom to decide its own lending policy. ${ }^{26}$

23. HAEU - BEI Création de la BEI-G. Sertoli 1004 Conférence intergouvernementale pour le Marché commun et l'Euratom - Groupe du Marché commun: PV des réunions des 24-26.09.1956 (MAE 361); HAEU - CM3 NEGO 248 Conférence intergouvernementale: histoire de l'article 129 du traité instituant la CEE, PV du Groupe du Marché Commun, 24-25-26.09.1956.

24. HAEU - BEI - 1003 Conférence intergouvernementale pour le Marché commun et l'Euratom Groupe du Marché commun, Proposition de rédaction des articles 63 à 65 présenté par la délégation française, 24.09.1956.

25. HAEU - CM3 NEGO 248 Conférence intergouvernementale: histoire de l'article 129 du traité instituant la CEE, Groupe du Marché commun, PV du Groupe du Marché commun, 24-25-26.09.1956; HAEU - BEI - 1001 Proposition de rédaction des articles 63 à 65 présentée par la délégation italienne, 24.09.1956; HAEU - BEI 1002 Comité des chefs de délégation «Note présentée par la délégation italienne sur les questions à soumettre aux ministres des Affaires étrangères», (MAE 329), 26.09.1956.

26. HAEU - CM3 NEGO 248 PV du Groupe du Marché commun, 24-25-26.09.1956. 
This difference of opinion on the function of the fund permeated the negotiations on other aspects of the institution. As for the formulation of the lending policy, all the governments agreed that the fund should be managed as a bank with credit criteria determined by the expected return of the investments. But whereas Germany and the Netherlands wanted the fund to follow only cost-effectiveness and economic utility criteria, Italy wanted the fund also to take social considerations into account, thereby allowing it to finance projects with a social dimension, even if the financial return would be low or nil. Thus, as the Italians conceived it, the fund could also grant financial aid and would not lend solely on the basis of return on investment. ${ }^{27}$

There was also disagreement with respect to the appropriate source of financial resources for the fund. The six governments agreed that the member states would, by subscription, provide the fund's initial capital which, on German insistence, would be denominated in US dollars and would amount to USD 1,000 million. The US currency was chosen in order to improve the fund's prospects for raising capital on the international market. France initially preferred the capital to be denominated in European Payments Union (EPU) units of account so that the fund would not be coupled with the currency of a third country, but it later decided to accept provisionally the German position. ${ }^{28}$ However, while Germany wanted the fund to obtain its required financial resources on the international capital markets, France and especially Italy advocated that the fund should be able to lend resources drawn from national budgets of the member states. Germany firmly repudiated this proposal on the grounds that such a possibility would weaken the incentive to raise capital on the international markets. As the richest of the six countries in terms of GDP, Germany feared that it would be called upon to make the greatest financial contribution to supply the bank's resources, and so it opposed forcefully the notion that the fund should be financed by charges upon the national budgets of its founding states. ${ }^{29}$

Since the six governments did not agree on the functions of the fund nor the methods for raising its financial resources, it was inevitable that they would also disagree upon the structure of the fund. Germany and the Netherlands argued that, if the fund was to be recognised as a credible borrower on international capital markets, it had to be guaranteed independence from the nation states. Accordingly, Germany proposed to establish a Board of governors, whose members, representing the member states, would fix the principles guiding the fund. A representative of the European Commission could also attend the meetings in a consultative capacity. Completing the governance structure, a Board of directors would be established with the right to decide on lending, together with an executive committee which would be responsible for the fund's day-to-day management. Thus, the Netherlands and Germany wanted to set up an independent institution, similar in many respects to the World Bank,

27. HAEU - BEI 1004 PV des réunions des 24-26.09.1956 (MAE 361).

28. HAEU - BEI - 1001 Proposition de rédaction des articles 63 à 65 présenté par la délégation française, 24.09.1956.

29. HAEU - BEI 1001 Exposé présenté par le porte-parole allemand (MAE 326), 24.09.1956; HAEU - BEI 1004 PV des réunion des 24-26.09.1956 (MAE 361). On this quarrel, see HAEU - BEI témoignage Sertoli, 28.10.1994. 
manifesting all the attributes necessary to confirm its autonomy and, therefore, credibility to the international capital markets. ${ }^{30}$

The Italian proposal was at odds with the German-Dutch model. Italy wanted the member states to maintain a certain political control over the fund, and so wanted the Council of ministers of the EEC to work out the fund's guidelines and to set its priorities. Because of Italy's perception of the fund's importance in implementing the common market, the Italian government wanted it to fall under the authority of the EEC Council of ministers and the Commission, thereby opening the fund to the political influence of the member states, which could shape the fund's credit policy in line with their priorities and preferences. Italy considered it unacceptable that the future EEC should have no ongoing power over the fund which, in practice, would turn out to be the only real supranational institution furnished with its own resources, its own legal personality and majority voting rule. The other delegations were not inclined to support the Italian proposal and decided instead to empower the fund to decide its own lending policy and to determine for itself how best to adapt to changing economic circumstances. ${ }^{31}$

The difficulties encountered in determining the structure of the fund stemmed from the need to reconcile two competing factors. On the one hand, the fund had been conceived as an element in the framework of the common market, so its underlying character was that of an institution of the EEC, with activities and functions linked to the EEC. On the other hand, as a financial institution that had to be able to raise funds on the international capital market, the fund needed to have a structure that could earn and maintain the best credit rating and, hence, it had to be free from the political influence of the member states. In the final phase of the negotiations the six governments were compelled to reach a compromise on these fundamental aspects of the fund's purpose and institutional design.

\section{Establishing a bank and not a fund}

Despite the fact that the Six intended to conclude the negotiations by the end of October 1956, it proved too difficult to resolve all of the outstanding issues before that deadline because of the complexity of the questions to be addressed and the technicalities involved. Only in February 1957 was a final agreement reached. This agreement was made possible by Germany's willingness to compromise on the func-

30. HAEU - BEI 1001 Exposé présenté par le porte-parole allemand (MAE 326), 24.09.1956; HAEU - BEI 1004 PV des réunion des 24-26.09.1956 (MAE 361).

31. HAEU - BEI 1002 Comité des chefs de délégation, «Note présentée par la délégation italienne sur les questions à soumettre aux ministres des Affaires étrangères», (MAE 329), 26.09.1956; HAEU - BEI 1005 Exposé du président du Groupe de Marché commun Hans von der Groeben, (MAE 373), 03.10.1956. 
tions on the fund, meeting some of the requests made by France and Italy, while maintaining its position on how the fund should be financed and structured.

The first breakthrough was achieved when the six delegations agreed to drop the notion of 'European interest and character' from the draft articles on account of its vagueness and geographical imprecision. At the same time, against the French and Italian insistence that this institution should be permitted to finance projects leading to the modernisation of a particular branch of the economy, Germany decided to soften its opposition whilst keep a firm attitude on the institutional structure on which the fund's credibility and hence its capacity to borrow depended. ${ }^{32}$

The Germans underlined the fund's need for a bank-like character, insisting that its lending policy had to be established by one of the fund's own organs, since this was the only way the fund might be identified as a credible borrower and, therefore, not be a charge on the budget of the member states. Germany was ready to accept the representation of the member states on the governing body of the fund, but because of the capital markets' general distrust of political organisations, it wanted this organ to be called the Board of governors, as it is named in the World Bank, rather than the Council of ministers, and did not want it to be formally part of the EEC. ${ }^{33}$ In this model governments would play a role, but within the setting of the fund itself and through an organ of the fund that could avoid giving the impression that it was dependent upon an external political institution, namely the EEC's Council of ministers, for its most important decisions. ${ }^{34}$

Italy, supported by France and Belgium, continued to oppose this position. The Italian government thought it crucial that the fund be an institution that was directed and controlled by member states and linked to the EEC, because this was the only way in which the fund might be capable of considering both economic and social issues in managing its operations. Thus, Italy maintained that the EEC Council of ministers was the appropriate body to set the general directives for the fund's investment activities and lending policy. Differences also existed on the function of the fund's Board of directors, the organ that would have the exclusive competence to approve loans. The directors would be appointed by the Council of ministers or Board of governors, which meant, in practice, that each member state would appoint its representatives. Germany wished its members to be independent of the states, while Italy wanted a stricter control on them. On voting procedure, Germany, France and the Benelux countries supported a weighting of votes according to the capital sub-

32. HAEU - BEI 1007 Groupe ad hoc pour le Fonds d'investissement: résumé des travaux du 8 octobre 1956; HAEU - BEI 1008 Résumé des travaux du 9 octobre 1956; HAEU - BEI - 1015 Résumé des travaux du 25 octobre 1956; HAEU - BEI - 1021 Rapport sur les travaux du Groupe ad hoc chargé d'élaborer le Statut du Fonds d'Investissement, 27.11.1956.

33. HAEU - BEI 1009 Groupe ad hoc pour le Fonds d'investissement: résumé des travaux du 10 octobre 1956.

34. HAEU - BEI - 1021 Rapport sur les travaux du Groupe ad hoc chargé d'élaborer le Statut du Fonds d'Investissement, 27.11.1956. 
scribed. Italy, on the contrary, held that each member of the Council should have one vote. 35

Even the naming of the fund, which would be an important means to communicate to international markets the character, credibility and functionality of the institution, was the subject of disagreement. During the negotiations both the CMG and the subgroup used the term 'fund' to describe the institution, but there remained a difference of opinion as to whether to adopt this term or the term 'bank' should be adopted. The same problem had arisen when the World Bank was created in 1944. Initially, the name chosen for that institution had been the International Investment Fund. After receiving an unenthusiastic response from American bankers, who had misgivings about the name in terms of the institution's credibility as a borrower, the 'bank' moniker had been adopted instead. Similarly in the European context, Germany and the Netherlands wanted the new institution to be called European Investments Bank. 36

The ad hoc group was able to agree on other aspects of the new entity's constitution, even though disagreement persisted on the issues of function and structure. First, it concluded that the fund would normally finance projects located in the territory of the members of the EEC. However, projects could also be located outside the territory of the member states, if the Council of ministers of the EEC agreed by unanimity to finance them. This was a concession to France, which wanted to enable the fund to finance projects in the French former colonies. In the negotiations on the common market, France had asked that the former colonies be given a preferential trade association with the Community and that the EEC members share in the financing of a development fund for those territories. The French government pursued a similar line in the negotiations concerning the fund, and was ultimately successful in broadening the scope of the fund to certain projects outside the EEC. ${ }^{37}$

Contrary to what had been decided in the $\mathrm{CMG}$, the ad hoc group dismissed the idea of adopting the US dollar as the fund's currency of reference. In line with the French suggestion, it adopted the EPU unit of account so that the fund could have a European linkage and not be pegged to the currency of an external third country. The ad hoc group also agreed on the principle of fixing the share of capital that member states would subscribe by deciding that each state's subscription would be determined on the bases of its GDP, its economic and political importance, and also the overall mission of the fund. It also agreed that France and Germany would subscribe the same share. 38

35. HAEU - BEI 1010 Groupe ad hoc pour le Fonds d'investissement: Résumé des travaux du 11 octobre 1956; HAEU - BEI 1020 Résumé des travaux du 14 novembre 1956; HAEU - BEI - 1021 Rapport sur les travaux du Groupe ad hoc chargé d'élaborer le Statut du Fonds d'Investissement, 27.11.1956.

36. HAEU - BEI - 1015 Résumé des travaux du 25 octobre 1956; HAEU - BEI - 1021 Rapport sur les travaux du Groupe ad hoc chargé d'élaborer le Statut du Fonds d'Investissement, 27.11.1956.

37. HAEU - BEI 1012 Résumé des travaux du 16 octobre 1956.

38. HAEU - BEI 1008 Résumé des travaux du 9 octobre 1956; HAEU - BEI - 1015 Résumé des travaux du 25 octobre 1956. HAEU - BEI - 1021 Rapport sur les travaux du Groupe ad hoc chargé d'élaborer le Statut du Fonds d'Investissement, 27.11.1956. 
At the end of November 1956, the six governments still disagreed on the nature, the character and the structure of governance of the fund. Yet, as negotiations on the common market neared their conclusion, the governments prepared themselves to make the concessions necessary to strike a final agreement. Germany accepted that the fund would be used to finance projects to support the reconversion, creation and modernisation of economic activities. However, it refused to accept the Italian demand that the fund be assigned a formal role in promoting the development of the disadvantaged regions. At the beginning of January 1957, Germany's stance on the structure of the fund was accepted. As a result, it was decided that the EEC Council of ministers would act as the fund's Board of governors but would be an organ of the fund, formally distinct from the EEC Council of ministers even though it would work with the same procedures and voting rules. Governments also agreed that, as the Germans had suggested, the fund would be called the 'European Investment Bank' in the hope of enhancing its credibility on the capital market. 39

The decision on establishing the Board of governors opened the way to an agreement on the Board of directors and the proportion of the capital to be paid up by the states. At the end of January 1957, the six countries agreed that they would pay up $25 \%$ of the capital to subscribe - as France had suggested - and they agreed also on the respective share each state had to subscribe. Initially the president of the CMG, Hans von der Groeben, suggested that 1 billion currency units would be required as the bank's start-up capital, with France and Germany each subscribing 325 million, and Italy and the Benelux countries 175 million each. As Germany and France would pay up more capital than Italy and the Benelux countries, they would be entitled to appoint more representatives to the Board of directors: Germany and France would appoint three directors, while Italy and the Benelux countries would each nominate two. Italy, which aspired to play a greater role, and which had sought equality with France and Germany during the negotiations concerning the other EEC institutions, opposed these suggestions. It aimed to have the same number of members on the Board of directors as France and Germany, and was also disposed to subscribe a higher share of capital. At the same time, Luxembourg made claims for a reduction in its subscription of capital, for which concession it was prepared to renounce its right to appoint a member of the Board of directors. ${ }^{40}$

The final decision was taken at the end of January 1957 by the Conference of the ministers of Foreign affairs, which decided that Germany and France would subscribe 300 million currency units, Italy 240 million, Belgium 86.5 million, Luxembourg 2 million, and the Netherlands 71.5 million. The Board of directors would consist of 12 members: France, Germany and Italy would each nominate three directors, the

39. HAEU - CM3 NEGO 115, Comité des chefs de délégation, PV de la réunion du 13-14.12.1956; ibid. CM3 NEGO 250 Comité des chefs de délégation, Propositions du président concernant les points à régler pour la Banque européenne d'Investissement, 27.12.1956.

40. HAEU - CM3 NEGO 250, Comité des chefs de délégation, PV de la réunion des chefs de délégation, 04-05.01.1957; ibid. Propositions du président concernant les points à régler pour la Banque Européenne d'Investissement, 27.12.1956; ibid., PV de la réunion des chefs de délégation, 26-28.01.1957. 
Benelux countries two and the Commission one. The European Commission would be represented with a right to vote, and the members of the Board of directors would be independent in carrying out their functions. As Italy had asked, the votes would not be weighted, but each member would have one vote. ${ }^{41}$

As a result of the negotiations, the European Investment Bank was established by articles 129 and 130 of the Treaty of Rome. The organisational and structural characteristics of the Bank were contained in the statute annexed to the Treaty. The EIB was given the role of promoting investments in the EEC by providing loans and guarantees, funded by borrowing on the international capital markets and from its own resources. Article 129 enumerated the types of projects which the EIB could finance: projects of regional interest; projects of interest to entire industrial sectors or to more than one member state; projects stimulating the development of the lessadvanced areas of the EEC; projects to modernise, convert or create European firms; and projects of common interest to more than one member stats that could not be financed in some other way. However, article 130 limited the role of the Bank by specifying that financial support for firms would be provided only when the size or the nature of the investment project exceeded national financing possibilities. It is worth noting that Italy did not succeed in its attempts to include in the Treaty formal recognition of the priority to be given to under-developed regions. However the preamble of the Treaty of Rome and article 2 mentioned the reduction of regional imbalances as a fundamental objective of the EEC. Moreover, in the protocol concerning Italy, attached to the Treaty of Rome, the Six recognized that the development of this country was a common objective of the EEC and that, therefore, an adequate share of EIB resources had to be allocated to this aim. ${ }^{42}$

The EIB would be overseen by a Board of governors composed of the ministers designated by each of the member states, usually the Finance ministers. It had the task of shaping the general directives on lending policy, approving the financial statements (including the balance sheet) and the annual report, making decisions on financing operations outside the EEC, and determining capital increases. In addition, the governors had responsibility for appointing the Board of directors, the Management Committee and the Audit Committee. In appointing the members of the Board of directors, the Board of governors would take nominations from the member states and from the European Commission. The directors had to ensure that the Bank would be managed in line with the provisions of the Treaty, the statute and the general directives laid down by governors. Most importantly the they had the exclusive competence to decide upon lending and borrowing operations, which they would do by majority voting. The third organ, the Management Committee was the collegiate and resident executive board. Under the authority of the president and the supervision of the Board of directors, it managed day-to-day business at the Bank, recommended decisions to the directors and was responsible for carrying them out. The president,

41. HAEU - CM3 NEGO 250 PV de la réunion des chefs de délégation, 26-28.01.1957.

42. HAEU, EIB Annual Report 1958. 
or in his absence one of the two vice-presidents, chaired the meeting of the Board of directors.

\section{Conclusion}

The Treaty of Rome was negotiated following the principle that mechanisms designed to increase competition ought to be complemented with measures aimed at ameliorating the negative effects of such increased competition. This principle from which the EIB stems has been a constant in the economic policy of the EU members and in the history of European Union.

The six governments attending the 1955 Messina conference had readily agreed on the need to establish an institution dealing with the investments as an instrument to ease economic integration and favour a balanced implementation of the common market. The idea was not new as it had already been proposed in 1949 in the OEEC framework. However it proved more difficult to agree on what this institution should actually do, its structure and, more broadly, whether it was better fashioned as a bank or a fund. Just as the six governments differed in their approach to the establishment of the common market, so their take on the investment institution also differed. As a result, its priorities, the way it would finance itself and its governance and management became a source of discussions among the six states of the ECSC.

When the European Investment Bank was finally established by the Treaty of Rome, the nascent institution had unique characteristics. The decision to establish a bank that could capably and efficiently borrow on the international capital markets prompted the members of the EEC to provide this institution with its own financial resources, legal personality and majority voting. Moreover, because of the crucial role the new institution was expected to play in ensuring the smooth and balanced transition to the common market, the EIB was created to be immediately effective and operational. This outline made the EIB a trustworthy actor on the international capital market and the most supranational of the institutions created by the EEC.

The EIB was negotiated by balancing two exigencies: that of establishing an EEC institution - therefore linked to the objectives and the economic policies of the member states - and, at the same time, that of creating a bank equipped to act effectively in the international capital markets. The resulting dual nature of the EIB has been its strength: since 1958, the scope of the EIB's activities has expanded considerably and has adjusted to the new environment and challenges. ${ }^{43}$ As the EEC and its successor the EU extended its field of action and developed an enlarged set of common policies, the EIB did the same by adapting its lending operations to the new circumstances. In the 1960s and 1970s the action of the Bank was linked to the nation state and was

43. For the action of the EIB since 1958, see E. BUSSIÈRE, M. DUMOULIN, E. WILLAERT (eds.), op.cit. 
concentrated on regional development. In the 1980s the Bank started to cooperate with non-state actors and, while retaining a leading and expanding role in regional policy, it broadened the scope of its activities by increasing its lending in the fields of energy and environmental protection, by adopting new technological innovation policies and favouring small and medium enterprises. Thus while regional development projects remained the EIB's major responsibility, the Bank diversified, extending its activities to new fields which were relevant to the umbrella organisation, the $\mathrm{EEC} / \mathrm{EU}$. In this sense, the EIB showed that it was able to adapt itself to new circumstances and to new priorities filtering down from policy decisions made at the $\mathrm{EEC} / \mathrm{EU}$ level.

The choice made in the Treaty of Rome to establish a financial institution independent of, but linked to, the EEC through the Boards of governors and directors has permitted the EIB to adapt itself in a flexible and pragmatic fashion to the new policies and problems of the EEC/EU. At the same time, the choice to set up a supranational institution gave credibility to the EIB that was able to obtain a leading role in the financial market and even received the AAA classification reserved for top-class issuers. In this sense, the EIB has played an important role in favouring the economic integration of the member states and the achievements of the aims set by the EU. 